\title{
Urinary proteomic shotgun approach for identification of potential acute rejection biomarkers in renal transplant recipients
}

Håvard Loftheim ${ }^{1,2}$, Karsten Midtvedt ${ }^{3}$, Anders Hartmann ${ }^{3}$, Anna V Reisæter ${ }^{3}$, Pål Falck ${ }^{2}$, Hallvard Holdaas ${ }^{3}$, Trond Jenssen ${ }^{3}$, Leon Reubsaet ${ }^{1}$ and Anders Åsberg ${ }^{2^{*}}$

\begin{abstract}
Background: Acute rejection (AR) episodes in renal transplant recipients are suspected when plasma creatinine is elevated and other potential causes out ruled. Graft biopsies are however needed for definite diagnosis. Noninvasive AR-biomarkers is an unmet clinical need. The urinary proteome is an interesting source in the search for such a biomarker in this population.

Methods: In this proof of principle study, serial urine samples in the early post transplant phase from 6 patients with biopsy verified acute rejections and 6 age-matched controls without clinical signs of rejection were analyzed by shotgun proteomics.

Results: Eleven proteins fulfilled predefined criteria for regulation in association with AR. They presented detectable regulation already several days before clinical suspicion of AR (increased plasma creatinine). The regulated proteins could be grouped by their biological function; proteins related to growth and proteins related to immune response. Growth-related proteins (IGFBP7, Vasorin, EGF and Galectin-3-binding protein) were significantly upregulated in association with $\mathrm{AR}(P=0.03)$ while proteins related to immune response (MASP2, C3, CD59, Ceruloplasmin, PiGR and CD74) tended to be up-regulated $(P=0.13)$.

Conclusion: The use of shotgun proteomics provides a robust and sensitive method for identification of potentially predictive urinary biomarkers of AR. Further validation of the current findings is needed to establish their potential clinical role with regards to clinical AR diagnosis.
\end{abstract}

Trial registration: ClinicalTrials.gov number NCT00139009

Keywords: Acute rejection, Biomarker, Renal transplantation, Urinary proteomics

\section{Background}

Patients whom experience an acute rejection (AR) after renal transplantation have an increased risk of developing chronic allograft nephropathy and reduced longterm graft survival [1-5]. In a clinical setting an AR is typically suspected upon an increase in plasma creatinine that cannot be explained by other plausible causes, and verified by histological examination of core biopsies from the graft [6]. This method is however flawed by both late and unspecific onset of plasma creatinine

\footnotetext{
* Correspondence: anders.asberg@farmasi.uio.no

2Department of Pharmaceutical Biosciences, School of Pharmacy, University of Oslo, Oslo, Norway

Full list of author information is available at the end of the article
}

increase and sampling heterogeneity and poor correlation with treatment response and prognosis for biopsy results.

Even though renal biopsying per se is considered a relatively safe procedure when appropriate clinical precautions are taken, it is a time-consuming invasive procedure which is cumbersome for the patients and has potential side effects [7]. In the general follow-up of transplanted patients a non-invasive method with high sensitivity and specificity for diagnosing AR is desirable. Of the many different methods and matrices plausible for such monitoring, the urinary proteome is maybe one of the most appropriate. It can be accessed non-invasively and the proteome reflects the last step in molecular regulation of

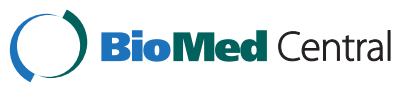


immune responses. About 30\% of the urinary proteome comes from plasma while the rest is locally produced in the kidney, increasing the possibility of reflecting kidney specific processes $[8,9]$. This is likely an advantage when monitoring graft function and events in kidney transplantation. Several attempts have been made to identify possible urinary biomarkers for AR [10-24], but none are currently used clinically $[25,26]$. Most of the studies done are hypothesis based and only focus on a few specific target proteins. The development in the field of mass spectrometry has, however, made screening analysis of the full proteome technically possible. Recently, Sigdel et al. used shotgun proteomics to identify proteins in pooled urine samples from pediatric kidney transplants with acute rejection [20].

We performed a small prospective proof of principle study in order to show the applicability of using shotgun proteomics in serial samples from distinct individuals in the search for urinary proteins that are regulated in association with AR episodes. In shotgun proteomics proteins are enzymatically digested into peptides, which are separated by liquid chromatography, coupled to a mass spectrometer, in this case a state of the art LTQ-Orbitrap. This enables analysis of the whole proteome in one experiment utilizing the increased sensitivity offered by MS-detection of peptides instead of intact proteins. The very complex peptide mixture resulting from tryptic digestion of proteins requires more molecular information for unambiguous identification, which is achieved by the use of tandem mass spectrometry. After the first mass scan energy is added to the peptides, resulting in fragmentation and cleavage into amino acids which can be detected in the next mass scan allowing peptide sequencing and subsequent protein identification by database searches. In order to quantify protein levels in this method, samples were labeled with the stable ${ }^{18} \mathrm{O}$ isotope and compared with respective baseline sample. The typical time-span of one single analysis is approximately 4-5 days, making this approach unsuitable for routine analysis. With this experimental setup the respective samples are mixed early in the process, acting as each other's controls, which eliminates many of the factors contributing to experimental variability.

\section{Patients and methods}

\section{Study design and samples}

We used urine samples from 6 renal transplant patients with BPAR during the first post transplant months and from 6 renal transplant patients with stable graft function in the same period, matched for age, immunosuppression and time after transplantation. All urine samples were collected prospectively as part of an at that time ongoing study of twenty renal transplant recipients at Oslo University Hospital, Rikshospitalet [27]. On average urine samples were available from $4.7 \pm 2.7$ days after transplantation and the patients were followed for $8-10$ weeks. All patients received induction with intravenous basiliximab on day 0 and 4 , cyclosporine $\mathrm{A}$ (CsA), mycophenolate mofetil $1 \mathrm{~g}$ BID and steroids. Urinary samples were collected three times weekly the first two weeks, twice weekly the next four weeks followed by 1-2 samples per week thereafter. Acute rejections were suspected based on plasma creatinine increase $(\geq 20 \%)$, after ruling out other potential causes such as bacterial infection or drug toxicity etc., and were verified by renal core biopsies (Banff 97 criteria) [6]. Urine samples from the day of BPAR were compared with the first available sample after transplantation (baseline) and from a clinically stable phase, approximately one week prior to rejection. In the control group no biopsies were obtained but urine samples from were attained at similar time points as in the AR-group.

The study was performed in accordance with the Declaration of Helsinki, local laws and regulations, including the Declaration of Helsinki and Declaration of Istanbul. The study was reviewed by the regional ethics committee and signed informed consent, covering also these urinary proteomics analyses, was obtained before study start from all patients. The trial EudraCT number is 2005-000219-90 and it is registered on www.clinicaltrials.gov (NCT00139009).

\section{Urine sample preparation}

Midstream urine was collected without the addition of protease inhibitors and allowed to rest at $4^{\circ} \mathrm{C}$ for up to one hour, after which it was centrifuged at $800 \times \mathrm{g}$ for 10 minutes and stored at $-70^{\circ} \mathrm{C}$. Sample preparation was performed as previously described $[28,29]$. In short, total protein concentrations was measured using Bradford's method [30] and the samples was normalized with respect to this, following cut-off filtration but prior to depletion. A volume of $300 \mu \mathrm{L}$ was transferred to Vivapure Anti-HSA kit (Vivascience Sartorius Group) for albumin depletion. Reduction of the proteins was done using DTT at $95^{\circ} \mathrm{C}$ for 15 minutes, followed by alkylation with iodoacetic acid in the dark at room temperature for 15 min. Tryptic digestion and ${ }^{18} \mathrm{O} /{ }^{16} \mathrm{O}$-labeling of the samples was done as described earlier [29]. The key parameters were as follows: A sample volume of $50 \mu \mathrm{L}$ was applied to immobilized trypsin beads and digested using a $\mathrm{pH} 8.0$ buffer at $37^{\circ} \mathrm{C}$ for 90 minutes under shaking $(1200 \mathrm{rpm})$. Subsequently, the samples were subjected to ${ }^{18} \mathrm{O} /{ }^{16} \mathrm{O}$-labeling using the same beads, but with a different buffer $(\mathrm{pH} 6.0)$ at $37^{\circ} \mathrm{C}$ for 3 hours under shaking (1200 rpm). Finally, the samples were purified and desalted by using in-house produced C18tips prior to 2D LC-MS/MS analysis. The AR samples were labeled with ${ }^{18} \mathrm{O}$ and mixed with both unlabeled 
baseline samples and unlabeled samples from a clinically stable phase (7-11 days prior to rejection) in the ARgroup. In the control group, the time matched samples after transplantation was labeled and mixed with unlabeled baseline samples.

\section{D LC-MS/MS}

Two-dimensional LC-MS/MS was used for separation and detection of the tryptic digested peptide mixture. Hydrophilic Interaction Liquid Chromatography (HILIC) was used as the first dimension of separation and was done exactly as described previously [28,29]. Fractions were collected every minute, in total 30 fractions per sample. All fractions were evaporated on a SpeedVac (Thermo) and reconstituted in $60 \mu \mathrm{L}$ of $2 \% \mathrm{MeCN}$ in $20 \mathrm{mM}$ formic acid. The nanoLC-MS/MS analysis was done using $20 \mu \mathrm{L}$ of reconstituted fractions as described earlier [29] but with a slightly modified HPLC setup: The reconstituted fractions were trapped on a C18 $5 \mathrm{~mm} \times 300 \mu \mathrm{m}$ id Acclaim PepMap $100(5 \mu \mathrm{m})$ enrichment column (Dionex). The loading mobile phase $20 \mathrm{mM}$ formic acid and $\mathrm{MeCN}(98 / 2, v / v)$ was delivered at $10 \mu \mathrm{L} / \mathrm{min}$ for 4 minutes. The sample was transferred to a $150 \times 0.075 \mathrm{~mm}$ id Acclaim PepMap 100 (pore size $100 \AA$ and particle diameter $3 \mu \mathrm{m}$; Dionex) at $300 \mathrm{~nL} /$ min. The mobile phases consisted of A: $20 \mathrm{mM}$ formic acid and $\mathrm{MeCN}(95 / 5, v / v)$ and B: $20 \mathrm{mM}$ formic acid and $\mathrm{MeCN}(5 / 95, v / v)$. A linear gradient was run from $0 \%$ to $50 \%$ B in 60 minutes. Subsequently, the elution strength was increased to $100 \%$.

The nanospray ionization (NSI) source was operated in the positive ionization mode $(360 \mu \mathrm{m}$ od $\times 20 \mu \mathrm{m}$ id distal coated fused silica emitter, $10 \mu \mathrm{m}$ id tip (New Objective, Woburn, MA, USA). Experiments were performed in two scan events; from $\mathrm{m} / \mathrm{z} 300$ to $\mathrm{m} / \mathrm{z} 2000$ in the FT-Orbitrap with resolution $R=30000$ and a data dependent MS/MS with wide band activation carried out on the highest $m / z$ value. The $m / z$ values fragmented were dynamically excluded for $15 \mathrm{sec}$ in order to fragment lower intensity $\mathrm{m} / \mathrm{z}$ values. Helium gas was used to cause collision-induced fragmentation at 35\% relative collision energy.

\section{Identification and selection of proteins}

The acquired MS data were analyzed and processed using Proteome Discoverer 1.2 (Thermo) software. The raw files were analyzed in 2 search nodes, where the first search node was a SEQUEST ${ }^{\mathrm{mm}}$ [31] search against the FASTA file ipi.HUMAN.v3.76. Carboxymethyl (C) was set as constant modification while oxidation $(\mathrm{M})$ and ${ }^{18} \mathrm{O}$ (2) on the $\mathrm{C}$-terminal were chosen as variable modifications. The peptide tolerance was set to $10 \mathrm{ppm}$ while MS/MS tolerance was $\pm 0.8 \mathrm{Da}$ and 2 "missed cleavages" were allowed using trypsin as enzyme. A decoy database search was performed by searching against a database containing the reversed protein sequences with a strict target false discovery rate (FDR) of 0.01 and a relaxed FDR of 0.05. Grouping of proteins were enabled and only the top ranked peptide hits below the FDR threshold $(<0.05)$ were accepted. The heavy label was set to ${ }^{18} \mathrm{O}(2)$ on the C-terminal, while the light channel contained no modifications. Only unique peptides were used for quantification and the labeled: unlabeled $\left({ }^{18} \mathrm{O}:{ }^{16} \mathrm{O}\right)$ ratios were adjusted against the protein median of all the quantified proteins in each patient.

Potentially clinically relevant regulation in this proof of principle study was defined as a fold change of $\geq 1$ $(\log 2)$ between baseline and follow-up in at least three patients in the rejection group but excluding proteins with significantly higher average ratio in the control group and proteins more frequently up-regulated in the control group.

\section{Statistics}

The nature of this kind of proof of principle studies makes relevant statistical analyses difficult. In attempt to provide a higher statistical power the regulated proteins were groups by their biological function. For the evaluation of the demographic data and comparison of the groups, the Mann-Whitney $U$ test was used. A $P$-value of $<0.05$ was considered statistical significant and all analyses were performed by Minitab version 16.1 (Minitab Inc., Coventry, UK).

\section{Results}

\section{Patient demographics}

Demographic data of the six patients with acute rejection and six controls are shown in Table 1. The patients in the AR-group experienced biopsy proven acute rejection (BPAR) episodes on average $42 \pm 27$ days after transplantation, all C4d negative. No significant differences were present between the groups with respect to recipient age, HLA mismatch or donor age. The baseline urine samples were obtained $5.0 \pm 3.6$ and $4.3 \pm 1.8$ days after transplantation in the AR- and control group, respectively.

\section{Up-regulated proteins during AR episodes}

A total of eleven proteins showed regulation according to the predefined criteria (Table 2). Ten of the proteins belonged to one of two main groups considering their biological function; proteins involved in regulation of growth and proteins involved in immune responses. Figure 1 presents a box plot of the eleven regulated proteins, grouped by biological function (average of ratios of the different proteins) and Meprin A subunit alpha (MEP1A), in the rejection group and in the controls. At the time of BPAR the growth factor proteins, as a group, were statistically 
Table 1 Demographic data at time of inclusion

\begin{tabular}{lcccc}
\hline & All & No-rejection group & Rejection group & P value \\
\hline Gender (male/female) & $7 / 5$ & $3 / 3$ & $4 / 2$ & $71.3 \pm 7.7$ \\
Weight (kg) & $75.7 \pm 10.2$ & $80.2 \pm 11.1$ & $50.5 \pm 15.8$ & 0.09 \\
Age (years) & $55.0 \pm 12.2$ & $59.5 \pm 5.4$ & $1.3 \pm 0.8$ & $1.2 \pm 0.8$ \\
HLA mismatch (A+B) & $1.2 \pm 0.9$ & $1.0 \pm 1.1$ & $0.5 \pm 0.5$ & 0.47 \\
HLA mismatch (DR) & $1.2 \pm 0.7$ & $1.2 \pm 0.8$ & $168 \pm 24$ & 0.00 \\
HLA mismatch (DQ) & $0.5 \pm 0.5$ & $0.4 \pm 0.5$ & $54.0 \pm 4.6$ & 0.06 \\
Serum creatinine & $143 \pm 48$ & $119 \pm 55$ & $5 / 6$ & 0.52 \\
Age donor (years) & $51.5 \pm 10.8$ & $49.0 \pm 14.8$ & $6 / 6$ &
\end{tabular}

Data are means $\pm S D$.

a at time of BPAR and matched time-points, respectively.

significant up-regulated in the AR-group $(P=0.03)$. Five of six patients showed regulation of these proteins above the predefined threshold. A trend towards up-regulation was also present for the immune response proteins in the ARgroup $(P=0.13)$, present in four out of six patients, while none of the control patients showed regulation. MEP1A was not detected in any of the control patients but significantly up-regulated in all four AR-patients in which the protein was detected. Figure 2 shows the log 2 changes in protein levels for the specified protein groups between baseline and the time of BPAR in the AR-group. The trend is that these regulated proteins are up-regulated already in the clinically stable samples, 7-11 days prior to the time of BPAR.

\section{Discussion}

The present analysis identified several up-regulated urinary proteins, but no relevantly down-regulated, in association with acute rejection episodes in the early post transplant phase after kidney transplantation. The results demonstrate the applicability of combining shotgun proteomics with relative quantification by ${ }^{18} \mathrm{O} /{ }^{16} \mathrm{O}$-labeling in biomarker discovery using sequential samples from several patients. This labeling allows determining the

Table 2 Up-regulated proteins ${ }^{\mathrm{a}}$ in AR/control urine samples compared to baseline shown for individual patients

\begin{tabular}{|c|c|c|c|c|c|c|c|c|c|c|c|c|c|}
\hline & & \multicolumn{6}{|c|}{ Rejection group } & \multicolumn{6}{|c|}{ No-rejection group } \\
\hline & & AR 1 & AR 2 & AR 3 & AR 4 & AR 5 & AR 6 & C 1 & C 2 & C 3 & C 4 & C 5 & C 6 \\
\hline & Banff classification & $\begin{array}{l}\mathrm{I}_{3} \mathrm{~T}_{1} \mathrm{~V}_{0} \\
\mathrm{C} 4 \mathrm{~d}-\end{array}$ & $\begin{array}{l}\mathrm{I}_{2} \mathrm{~T}_{2} \mathrm{~V}_{0} \\
\mathrm{C} 4 \mathrm{~d}-\end{array}$ & $\begin{array}{l}\mathrm{I}_{2} \mathrm{~T}_{2} \mathrm{~V}_{0} \\
\mathrm{C} 4 \mathrm{~d}-\end{array}$ & $\begin{array}{l}\mathrm{I}_{2} \mathrm{~T}_{2} \mathrm{~V}_{0} \\
\mathrm{C} 4 \mathrm{~d}-\end{array}$ & $\begin{array}{l}\mathrm{I}_{2} \mathrm{~T}_{3} \mathrm{~V}_{0} \\
\mathrm{C} 4 \mathrm{~d}-\end{array}$ & $\begin{array}{l}\mathrm{I}_{3} \mathrm{~T}_{1} \mathrm{~V}_{2} \\
\mathrm{C} 4 \mathrm{~d}-\end{array}$ & NA & NA & NA & NA & NA & NA \\
\hline Gene ID & Protein name & & & $\log 2 c$ & hange & & & & & $\operatorname{og} 2$ & chang & & \\
\hline \multicolumn{14}{|l|}{ Immune proteins } \\
\hline IPI00217775.1CD74 & $\begin{array}{l}\text { Isoform } 2 \text { of HLA class II histocompatibility } \\
\text { antigen gamma chain }\end{array}$ & $N D^{b}$ & 0.47 & 2.57 & 4.06 & 1.81 & 1.23 & 0.39 & 1.03 & 0.81 & 0.99 & 2.10 & 0.58 \\
\hline IPI00004573.2PIGR & Polymeric immunoglobulin receptor & -0.04 & 0.66 & 2.27 & 1.31 & 0.36 & 2.20 & 0.29 & 0.63 & 0.71 & 1.65 & 0.19 & 0.14 \\
\hline IPI00783987.2C3 & Complement C3 (Fragment) & -0.17 & 3.17 & -0.48 & 1.25 & -5.32 & 2.64 & -3.49 & ND & 1.14 & -4.80 & -1.54 & -3.63 \\
\hline IPI00017601.1CP & Ceruloplasmin & 0.42 & 4.40 & 0.34 & 1.15 & ND & 4.79 & -1.87 & $7-1.25$ & 0.22 & -1.02 & 0.53 & -2.02 \\
\hline IPI00306378.5MASP2 & $\begin{array}{l}\text { Isoform } 2 \text { of Mannan-binding lectin serine } \\
\text { protease } 2\end{array}$ & 1.10 & 1.88 & 1.36 & 2.30 & 1.26 & 4.06 & 0.57 & -3.94 & 1.94 & 1.19 & 2.44 & 0.43 \\
\hline IPI00011302.1CD59 & CD59 glycoprotein & -2.65 & 1.16 & 1.30 & 1.74 & 0.40 & 3.62 & -1.52 & 2.68 & -1.90 & 1.73 & 1.31 & 0.19 \\
\hline \multicolumn{14}{|l|}{ Growth factors } \\
\hline IPI00016915.1IGFBP7 & Insulin-like growth factor-binding protein 7 & 0.11 & -0.43 & 2.40 & 1.01 & -0.91 & 2.84 & 0.71 & 1.42 & 0.05 & 0.58 & -0.02 & ND \\
\hline IPI00966866.1EGF & Epidermal growth factor & 1.71 & 3.49 & 2.15 & 0.75 & 0.97 & ND & 0.79 & ND & ND & 1.51 & 0.51 & 0.13 \\
\hline IPI00395488.2VASN & Vasorin & 1.27 & 1.11 & ND & 0.61 & 0.05 & 2.10 & 0.96 & -2.27 & 2.00 & 0.66 & 1.69 & -0.81 \\
\hline IPI00023673.1LGALS3BP & PGalectin-3-binding protein & 1.01 & 0.20 & 2.62 & 1.76 & 0.61 & 3.59 & 0.26 & 1.21 & 0.03 & 1.15 & 0.32 & 0.30 \\
\hline \multicolumn{14}{|l|}{ Other } \\
\hline IPI00004372.3MEP1A & MEP1A protein (Meprin A subunit alpha) & ND & ND & 1.87 & 2.87 & 1.31 & 1.02 & ND & ND & ND & ND & ND & ND \\
\hline
\end{tabular}

${ }^{a}$ Criteria for up-regulation: up-regulation (log 2 change $\geq 1$ ) from baseline to AR in at least three patients in the AR-group. Proteins with higher average ratio in the control group and proteins more frequently up-regulated in the control group were excluded. ${ }^{\mathrm{b}}$ ND: Not detected. 


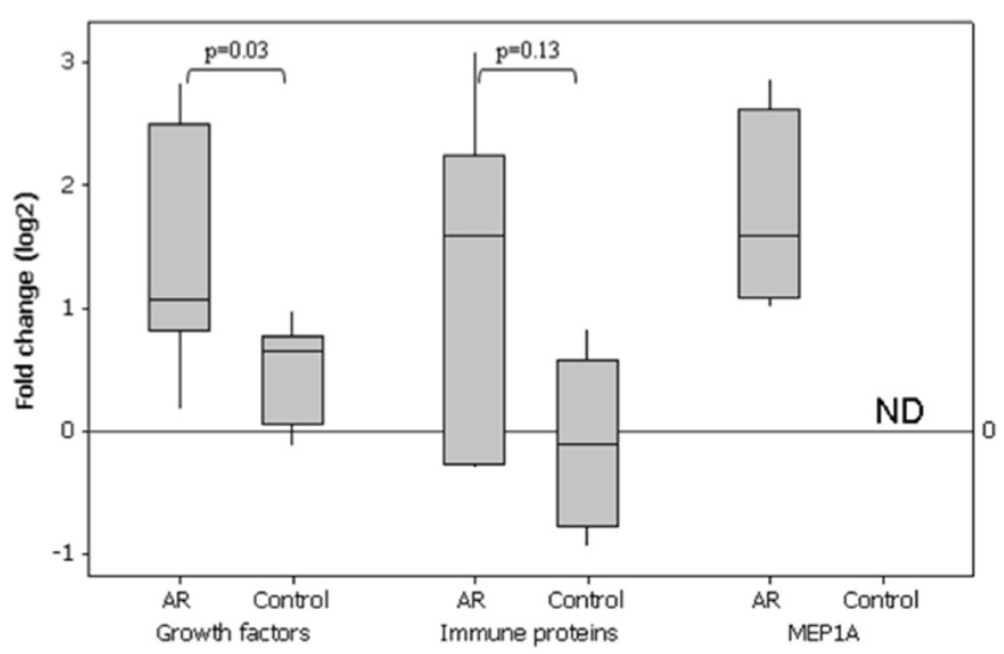

Figure 1 Box plot showing fold change (log2) of immune proteins, growth factors and MEP1A from baseline to acute rejection in the AR-group compared with the control group.

relative amount of the proteins identified of two complex samples in one single analysis. Since sample handling is long, consist of many steps, is laborious and susceptible to variations, it is a necessity to mix the two samples early during this procedure. By doing this, errors caused by variations in individual sample handling are excluded thus producing a more reliable determination of the separate protein amounts. By comparing baseline and event samples in the two groups each patient serve as its own control. This approach, as compared to the more commonly used pooled sample strategy, gives a more informative picture since interindividual variability can be assessed. Although several additional validation studies are needed, the proteins found to be regulated in the present study may be potential biomarkers for acute rejection episodes in renal transplantation. The up-regulation was detected already several days prior to the acute rejection was clinically suspected (increased creatinine). This is an interesting finding since in addition to being non-invasive the urinary proteome may hence also provide a more sensitive diagnostic approach for AR. Acute rejection episodes are a gradual processes and if the altered urine proteome turns out to be an earlier responding, and more specific, biomarker of AR it could have dramatic implications on follow-up of renal transplant recipients and their longterm outcome. It is plausible that only a minor adjustment of the immunosuppressive therapy is required to "silence" the activated immune process in an early phase, and hence avoid full activation.

In the nature of this kind of proof of principle study, sufficiently powered statistical analyses are difficult to perform. Looking at the data descriptively, only the Mannan-binding lectin serin protease 2 (MASP2) was up-regulated in all patients with AR. The extent of regulation of each protein differed individually as showed in Table 2, without any obvious pattern. In an attempt to provide a relevant statistical comparison proteins were grouped by biological function. This substantiated a potentially relevant regulation in the rejection group also of the other ten identified proteins. The data may also indicate a connection between severity of the AR and the protein regulation as the only patient with arterial changes (Banff 2 A) showed an almost universally upregulation (10 of 11 identified proteins elevated and the last not detected). The patient who only experienced a borderline rejection further supports this hypothesis as only a relatively low degree of regulation was seen (4 of 11 proteins). The possibility to look at regulation patterns of more than one protein is an advantage of the applied method and can be crucial when looking for biomarker candidates.

For the proteins related to immune response, a strong up-regulation was observed in 4 of the AR-patients. The two remaining patients, one with only a borderline rejection actually showed a slight down-regulation. This was mostly due to a strong down-regulation of acute phase proteins Complement C3 and CD59 glycoprotein, respectively. In the control group most of the patients showed decreased levels of immune proteins, especially for the acute phase proteins.

Earlier studies present data supporting a relevant contribution of many of these proteins in AR episodes. For example, the pro-inflammatory cytokine Macrophage migration inhibitory factor (MIF), the extracellular ligand for CD74 [32,33], has been associated with AR in kidney transplants [10]. MASP2, polymeric immunoglobulin receptor, Ceruloplasmin and participants in the complement 


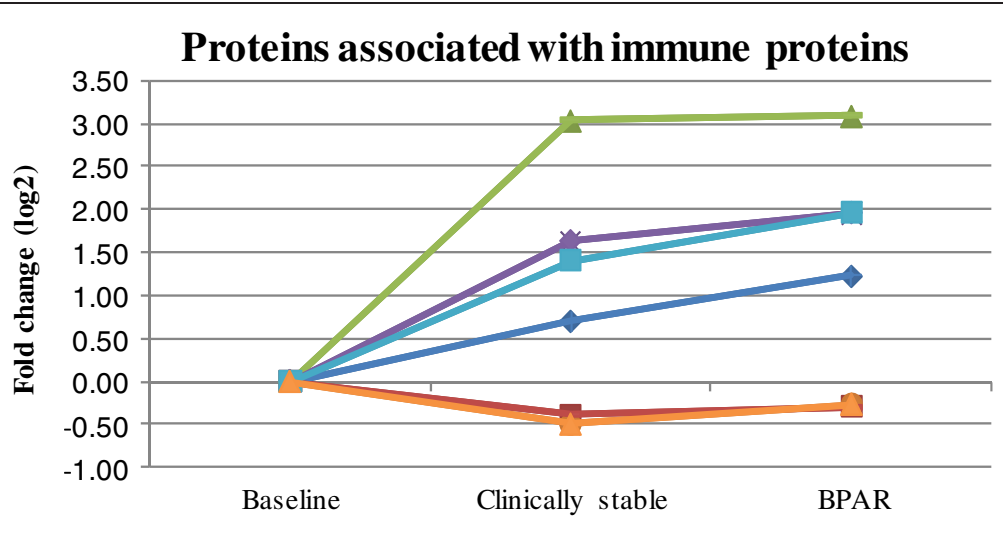

Urine sample (time)



Urine sample (time)

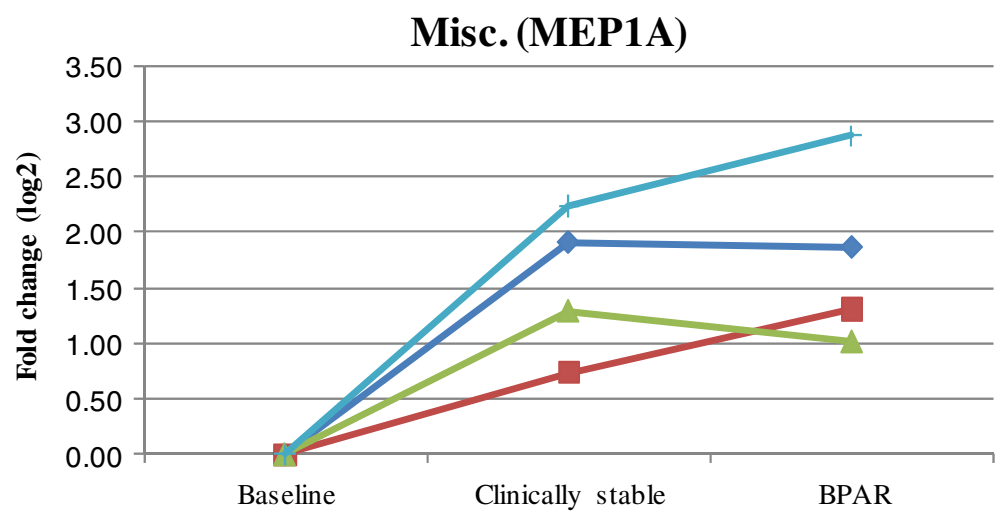

Urine sample (time)

Figure 2 Fold change (log2) of immune proteins, growth factors and MEP1A in the rejection group, AR1 (•) AR2 (x) AR3 (४) AR4 (+) AR5 (-) AR6 ( $\mathbf{\Lambda}$ ), from baseline to Biopsy Proven Acute Rejection (BPAR). The center point (Clinically stable) is 7-11 days before BPAR, at stable serum creatinine levels.

system have also been shown to be regulated in association with AR [20,34-39].

Cell growth proteins were up-regulated in five of six patients in the AR-group and are involved in several AR processes. Insulin-like growth factor-binding protein 7 (IGFBP7) modulate effects of vascular endothelial growth factor (VEGF) [40] and is reported to interact with Chemokines in venous endothelium including IFN- $\gamma$-inducible protein 10 (IP-10; CXCL10) [41,42], which has previously been reported to be elevated in urine in connection with AR [13,17]. Vasorin and Galectin-3-binding protein are closely associated to transforming growth 
factor-beta (TGF- $\beta_{1}$ ) and IL-6, both linked to acute rejection in this population [15,43-48].

MEP1A protein does not fit to either of the two protein groups and was only detected in the AR-group, significantly up-regulated at the time of AR. The absence of identified MEP1A in the control group is an interesting observation and could potentially be very useful in a diagnostic setting. It should however be kept in mind that this is only a proof of principle study so a wide range of further validation series have to be performed to ensure that the observations are clinically relevant.

Many urinary proteins that previously have been shown to be regulated in association with AR were also detected in our study, but not regulated enough to fulfill the predefined criteria [20] [49]. In addition, other proteins have been investigated using a more targeted approach (e.g. ELISA) but these were not confirmed by our investigation [10-19,21].

In addition to looking at the whole proteome a major strength of our analysis is that each patient was his or her own control, comparing the protein levels at baseline with sequential follow-up time points, in a well defined patient population. This allowed us to show that the proteins were regulated already several days before clinical suspicion of AR. In addition, individual samples were analyzed in the present study, not pooled urine, providing more detailed information of the regulation in association with the AR. The current study lack however a post treatment sample in order to be perfectly complete. With such a sample it would have proven that the regulation was specific to acute rejection episodes. Unfortunately such samples were not collected. Another indication of the relevance of the current findings is that all identified proteins are physiological plausible to be involved in an acute rejection episode. The major limitation of this proof of principle study is the relative limited small sample-size compared to classical approaches. This, however, has its cause in the time consuming and labor intensive nature of the full shotgun proteomic approach chosen. Even though it is applicable for first identification of potential biomarkers, analysis of each digested sample took almost one week to finalize. Somewhat overlap in analysis is possible but in general it is a too labor demanding procedure for large studies. In future validation of the present findings a more targeted analytical approach has to be utilized. It should also be pointed out that the control group patients were not verified non-rejectors by protocol biopsies. Previous studies have shown an incidence of almost 30\% subclinical rejections in apparently stable patients on CsA based immunosuppression [50,51]. It is hence possible that sub-clinical rejections could be present in some of the controls, making the interpretation somewhat biased. Further prospective studies are needed in larger populations, where biopsies also are performed in the controls, to fully elucidate on the involvement of these proteins in AR and their potential usability as diagnostic biomarkers.

\section{Conclusion}

This study shows the applicability of shotgun proteomics in combination with relative quantification by ${ }^{18} \mathrm{O} /{ }^{16} \mathrm{O}$ labeling in biomarker discovery in sequential urine samples. Two groups of physiological related proteins with relevance to immunological processes during AR episodes were found to be up-regulated in patients with BPAR.

\section{Competing interests}

The authors declare that they have no competing interests.

\section{Authors' contributions}

HL developed the proteomic method, designed the proteomic analysis part, performed all analyses, interpreted the results and wrote the paper. KM designed the study and the proteomic analysis part, performed the clinical trial and wrote the paper. AH designed the study, performed the clinical trial and commented on the paper. AVR performed the clinical trial and commented on the paper. PF designed the study, performed the clinical trial and commented on the paper. $\mathrm{HH}$ performed the clinical trial and commented on the paper. TJ performed the clinical trial and commented on the paper. LR developed the proteomic method and designed the proteomic analysis part and wrote the paper. $A \AA$ designed the study and the proteomic analysis part, performed the clinical trial and wrote the paper. All authors read and approved the final manuscript.

\section{Acknowledgements}

A special thanks to Kirsten K. Lund, Janicke Narverud and Jean Stenstrøm for taking care of the logistics of urine sample collection. The study was completely financed by internal budgets at the affiliated institutions.

\section{Author details}

${ }^{1}$ Department of Pharmaceutical Chemistry, School of Pharmacy, University of Oslo, P.O.Box. 1068Blindern, NO-0316, Oslo, Norway. ${ }^{2}$ Department of Pharmaceutical Biosciences, School of Pharmacy, University of Oslo, Oslo, Norway. ${ }^{3}$ Department of Transplant Medicine, Oslo University Hospital, Rikshospitalet, Norway.

Received: 8 February 2012 Accepted: 2 August 2012

Published: 31 August 2012

\section{References}

1. Almond PS, Matas A, Gillingham K, Dunn DL, Payne WD, Gores P, Gruessner R, Najarian JS, Ferguson, Paul, Schaffer: Risk-Factors for Chronic Rejection in Renal-Allograft Recipients. Transplantation 1993, 55(4):752-757.

2. Hariharan S, Johnson CP, Bresnahan BA, Taranto SE, Mclntosh MJ, Stablein D: Improved Graft Survival after Renal Transplantation in the United States, 1988 to 1996. N Eng J Med 2000, 342(9):605-612.

3. Kaplan B: Overcoming barriers to long-term graft survival. Am J Kidney Dis 2006, 47(4):S52-S64.

4. Meier-Kriesche HU, Ojo AO, Hanson JA, Cibrik DM, Punch JD, Leichtman AB, Kaplan B: Increased impact of acute rejection on chronic allograft failure in recent era. Transplantation 2000, 70(7):1098-1100.

5. Nankivell BJ, Chapman JR: Chronic allograft nephropathy: current concepts and future directions. Transplantation 2006, 81(5):643-654.

6. Racusen LC, Solez K, Colvin RB, Bonsib SM, Castro MC, Cavallo T, Croker BP, Demetris AJ, Drachenberg CB, Fogo AB, Furness P, Gaber LW, Gibson IW, Glotz D, Goldberg JC, Grande J, Halloran PF, Hansen HE, Hartley B, Hayry PJ, Hill CM, Hoffman EO, Hunsicker LG, Lindblad AS, Marcussen N, Mihatsch MJ, Nadasdy T, Nickerson P, Olsen TS, Papadimitriou JC, et al: The Banff 97 working classification of renal allograft pathology. Kidney Int 1999, 55(2):713-723

7. Reichelt $O$, Müller J, von Eggeling F, Driesch D, Wunderlich H, Schubert J, Gröne $\mathrm{H}-J$, Stein $\mathrm{G}, \mathrm{Ott} \mathrm{U}$, Junker K: Prediction of renal allograft rejection by urinary protein analysis using ProteinChip Arrays (surface-enhanced 
laser desorption/ionization time-of-flight mass spectrometry). Urology 2006, 67(3):472-475.

8. Pieper R, Gatlin CL, McGrath AM, Makusky AJ, Mondal M, Seonarain M, Field E, Schatz CR, Estock MA, Ahmed N, Anderson NG, Steiner S:

Characterization of the human urinary proteome: A method for highresolution display of urinary proteins on two-dimensional electrophoresis gels with a yield of nearly 1400 distinct protein spots. Proteomics 2004, 4(4):1159-1174.

9. Thongboonkerd V: Recent progress in urinary proteomics. Proteomics Clin App/ 2007, 1(8):780-791.

10. Brown FG, Nikolic-Paterson DJ, Chadban SJ, Dowling J, Jose M, Metz CN, Bucala R, Atkins RC: Urine macrophage migration inhibitory factor concentrations as a diagnostic tool in human renal allograft rejection. Transplantation 2001, 71:(12)1777-1783.

11. Donadio C, Puccini R, Lucchesi A, Giordani R, Rizzo G: Urinary excretion of proteins and tubular enzymes in renal transplant patients. Ren Fail 1998, 20(5):707-715.

12. Gupta RK, Jain M, Sharma RK: Serum \& urinary interleukin-2 levels as predictors in acute renal allograft rejection. Indian J Med Res 2004, 119:24-27.

13. Hauser IA, Spiegler S, Kiss E, Gauer S, Sichler O, Scheuermann EH, Ackermann H, Pfeilschifter JM, Geiger H, Gröne H-J, Radeke HH: Prediction of Acute Renal Allograft Rejection by Urinary Monokine Induced by IFNY (MIG). J Am Soc Nephrol 2005, 16(6):1849-1858.

14. Hu H, Aizenstein BD, Puchalski A, Burmania JA, Hamawy MM, Knechtle SJ: Elevation of CXCR3-Binding Chemokines in Urine Indicates Acute RenalAllograft Dysfunction. Am J Transplant 2004, 4(3):432-437.

15. Kaden J, Priesterjahn R: Increasing urinary IL-6 levels announce kidney graft rejection. Transpl Int 2000, 13:S34-S41.

16. Lederer SR, Friedrich N, Regenbogen C, Getto R, Toepfer M, Sitter T: NonInvasive Monitoring of Renal Transplant Recipients: Urinary Excretion of Soluble Adhesion Molecules and of the Complement-Split Product C4d. Nephron Clin Pract 2003, 94(1):c19-c26.

17. Matz M, Beyer J, Wunsch D, Mashreghi MF, Seiler M, Pratschke J, Babe $\mathrm{N}$, Volk HD, Reinke P, Kotsch K: Early post-transplant urinary IP-10 expression after kidney transplantation is predictive of short- and long-term graft function. Kidney Int 2006, 69(9):1683-1690.

18. Oetting WS, Rogers TB, Krick TP, Matas AJ, Ibrahim HN: Urinary beta(2)microglobulin is associated with acute renal allograft rejection. Am J Kidney Dis 2006, 47(5):898-904

19. Roelofs JJTH, Rowshani AT, Van Den Berg JG, Claessen N, Aten J, Ten Berge $\mathrm{JJM}$, Weening JJ, Florquin S: Expression of urokinase plasminogen activator and its receptor during acute renal allograft rejection. Kidney Int 2003, 64(5):1845-1853.

20. Sigdel TK, Kaushal A, Gritsenko M, Norbeck AD, Qian W-J, Xiao W, Camp DG II, Smith RD, Sarwal MM: Shotgun proteomics identifies proteins specific for acute renal transplant rejection. Proteomics Clin Appl 2010, 4(1):32-47.

21. Teppo AM, von Willebrand E, Honkanen E, Ahonen J, Gronhagen-Riska C: Soluble intercellular adhesion molecule-1 (sICAM-1) after kidney transplantation: The origin and role of urinary sICAM-1? Transplantation 2001, 71(8):1113-1119.

22. Clarke W, Silverman BC, Zhang Z, Chan DW, Klein AS, Molmenti EP: Characterization of renal allograft rejection by urinary proteomic analysis. Ann Surg 2003, 237(5):660-664.

23. Schaub S, Rush D, Wilkins J, Gibson IW, Weiler T, Sangster K, Nicolle L, Karpinski M, Jeffry J, Nickerson P: Proteomic-based detection of urine proteins associated with acute renal allograft rejection. J Am Soc Nephrol 2004, 15(1):219-227.

24. Wittke S, Haubitz M, Walden M, Rohde F, Schwarz A, Mengel M, Mischak H, Haller $\mathrm{H}$, Gwinner W: Detection of acute tubulointerstitial rejection by proteomic analysis of urinary samples in renal transplant recipients. Am J Transplant 2005, 5(10):2479-2488.

25. Gwinner W: Renal transplant rejection markers. World J Urol 2007. 25(5):445-455.

26. Thongboonkerd V, Malasit P: Renal and urinary proteomics: Current applications and challenges. Proteomics 2005, 5(4):1033-1042.

27. Falck P, Asberg A, Guldseth $H$, Bremer $S$, Akhlaghi F, Reubsaet JLE, Pfeffer P, Hartmann A, Midtvedt K: Declining intracellular T-lymphocyte concentration of cyclosporine a precedes acute rejection in kidney transplant recipients. Transplantation 2008, 85(2):179-184.

28. Loftheim H, Nguyen TD, Malerød H, Lundanes E, Åsberg A, Reubsaet L: 2-D hydrophilic interaction liquid chromatography-RP separation in urinary proteomics - Minimizing variability through improved downstream workflow compatibility. J Sep Sci 2010, 33(6-7):864-872.

29. Loftheim $H$, Åsberg A, Reubsaet L: Accelerated 180 -labeling in urinary proteomics. J Chromatogr A 2010, 1217(52):8241-8248.

30. Bradford MM: Rapid and Sensitive Method for Quantitation of Microgram Quantities of Protein Utilizing Principle of Protein-Dye Binding. Anal Biochem 1976, 72(1-2):248-254.

31. Eng JK, McCormack AL, Yates JR: An Approach to Correlate Tandem MassSpectral Data of Peptides with Amino-Acid-Sequences in a Protein Database. J Am Soc Mass Spectrom 1994, 5(11):976-989.

32. Leng L, Metz CN, Fang Y, Xu J, Donnelly S, Baugh J, Delohery T, Chen Y, Mitchell RA, Bucala R: MIF Signal Transduction Initiated by Binding to CD74. J Exp Med 2003, 197(11):1467-1476.

33. Lan HY: Role of Macrophage Migration Inhibition Factor in Kidney Disease. Nephron Exp Nephrol 2008, 109(3):e79-e83.

34. Borghese F, Clanchy Fl: CD74: an emerging opportunity as a therapeutic target in cancer and autoimmune disease. Expert Opin Ther Targets 2011, 15(3):237-251.

35. Kumar P, Kodlin D, Marks C, Leech SH: Predictive value of serum complement (C3) in renal allograft rejection. Br J Surg 1980, 67(7):500-502

36. Tang S, Zhou W, Sheerin NS, Vaughan RW, Sacks SH: Contribution of Renal Secreted Complement C3 to the Circulating Pool in Humans. J Immunol 1999, 162(7):4336-4341.

37. Segarra A: Progress in understanding the pathogenesis of $\lg A$ nephropathy: New perspectives for the near future? Nefrologia 2010, 30(5):501-507.

38. Panichi V, Migliori M, De Pietro S, Taccola D, Andreini B, Metelli MR, Giovannini L, Palla R: The link of biocompatibility to cytokine production. Kidney Int 2000, 58(S76):S96-S103.

39. Matsushita M, Thiel S, Jensenius JC, Terai I, Fujita T: Proteolytic Activities of Two Types of Mannose-Binding Lectin-Associated Serine Protease. J Immunol 2000, 165(5):2637-2642.

40. Tamura K, Hashimoto K, Suzuki K, Yoshie M, Kutsukake M, Sakurai T: Insulinlike growth factor binding protein-7 (IGFBP7) blocks vascular endothelial cell growth factor (VEGF)-induced angiogenesis in human vascular endothelial cells. Eur J Pharmacol 2009, 610(1-3):61-67.

41. Nagakubo D, Murai T, Tanaka T, Usui T, Matsumoto M, Sekiquchi K, Miyasaka M: A High Endothelial Venule Secretory Protein, Mac25/Angiomodulin, Interacts with Multiple High Endothelial Venule-Associated Molecules Including Chemokines. J Immunol 2003, 171(2):553-561.

42. Usui T, Murai T, Tanaka T, Yamaguchi K, Nagakubo D, Lee CM, Kiyomi M, Tamura S, Matsuzawa Y, Miyasaka M: Characterization of mac25/ angiomodulin expression by high endothelial venule cells in lymphoid tissues and its identification as an inducible marker for activated endothelial cells. Int Immunol 2002, 14(11):1273-1282.

43. Campistol JM, Iñigo P, Larios S, Bescos M, Oppenheimer F: Role of transforming growth factor- $\beta 1$ in the progression of chronic allograft nephropathy. Nephrol Dial Transplant 2001, 16(suppl 1):114-116.

44. Ikeda Y, Imai Y, Kumagai H, Nosaka T, Morikawa Y, Hisaoka T, Manabe I, Maemura K, Nakaoka T, Imamura T, Miyazono K, Komuro I, Nagai R, Kitamura T: Vasorin, a transforming growth factor $\beta$-binding protein expressed in vascular smooth muscle cells, modulates the arterial response to injury in vivo. Proc Natl Acad Sci USA 2004, 101(29):10732-10737.

45. Shihab FS, Tanner AM, Shao Y, Weffer MI: Expression of TGF-[beta]1 and matrix proteins is elevated in rats with chronic rejection. Kidney Int 1996, 50(6):1904-1913.

46. Fukaya $Y$, Shimada $H$, Wang L-C, Zandi E, DeClerck YA: Identification of Galectin-3-binding Protein as a Factor Secreted by Tumor Cells That Stimulates Interleukin-6 Expression in the Bone Marrow Stroma. J Biol Chem 2008, 283(27):18573-18581.

47. Ullrich A, Sures I, D'Egidio M, Jallal B, Powell TJ, Herbst R, Dreps A, Azam M Rubinstein $\mathrm{M}$, Natoli C: The secreted tumor-associated antigen $90 \mathrm{~K}$ is a potent immune stimulator. J Biol Chem 1994, 269(28):18401-18407.

48. Di Paolo S, Gesualdo L, Stallone G, Ranieri E, Schena FP: Renal expression and urinary concentration of EGF and IL-6 in acutely dysfunctioning kidney transplanted patients. Nephrol Dial Transplant 1997, 12(12):2687-2693.

49. O'Riordan E, Orlova TN, Podust VN, Chander PN, Yanagi S, Nakazato M, Hu R, Butt K, Delaney V, Goligorsky MS: Characterization of urinary peptide 
biomarkers of acute rejection in renal allografts. Am J Transplant 2007, 7(4):930-940.

50. Nickerson P, Jeffery J, Gough J, Grimm P, Mckenna R, Birk P, Rush D: Effect of Increasing Baseline Immunosuppression on the Prevalence of Clinical and Subclinical Rejection: A Pilot Study. J Am Soc Nephrol 1999, 10(8):1801-1805.

51. Rush DN, Henry SF, Jeffery JR, Schroeder TJ, Gough J: Histological-findings in early routine biopsies of stable renal-allograft recipients.

Transplantation 1994, 57(2):208-211.

doi:10.1186/2047-1440-1-9

Cite this article as: Loftheim et al.: Urinary proteomic shotgun approach

for identification of potential acute rejection biomarkers in renal

transplant recipients. Transplantation Research 2012 1:9.

\section{Submit your next manuscript to BioMed Central and take full advantage of:}

- Convenient online submission

- Thorough peer review

- No space constraints or color figure charges

- Immediate publication on acceptance

- Inclusion in PubMed, CAS, Scopus and Google Scholar

- Research which is freely available for redistribution 